\title{
PROSES PEMBELAJARAN MENGGUNAKAN KEANEKARAGAMAN BUNGA DAN BUAH SEBAGAI MEDIA PERMAINAN PADA SISWA TK LABIBAH BALIKPAPAN
}

\author{
Rahayu Sri Waskitoningtyas \\ Universitas Balikpapan \\ Email : rahayu.sri@uniba-bpn.ac.id
}

\begin{abstract}
This study aims to improve students' understanding and awareness of the importance of flowers and fruit as a learning process. This research was conducted at LABIBAH Kindergarten located at Jalan Ruhui Rahayu II RT. 99 No. 71 Balikpapan. The subject of this study was given to LABIBAH kindergarten students. Students can apply the material that has been delivered while at home, especially about children's play from flowers and fruit, so children love traditional games. In addition students are also aware of the importance of traditional games so as to foster children's creativity.
\end{abstract}

Keywords: Child Games, Flowers, Fruits

\begin{abstract}
Abstrak. Penelitian ini bertujuan untuk meningkatkan pemahaman dan kesadaran siswa tentang pentingnya bunga dan buah sebagai proses pembelajaran. Penelitian ini di lakukan di TK LABIBAH yang berlokasi di Jalan Ruhui Rahayu II RT. 99 No. 71 Balikpapan. Subyek penelitian ini diberikan pada siswa TK LABIBAH. Siswa dapat mengaplikasikan materi yang telah disampaikan ketika berada di rumah, terutama tentang permainan anak dari bunga dan buah, sehingga anak menyukai permainan tradisional. Selain itu siswa juga sadar akan pentignya permainan tradisional sehingga menumbuhkan kreativitas anak.
\end{abstract}

Kata Kunci: Permainan Anak, Bunga, Buah

\section{PENDAHULUAN}

Pemanfaatan keanekaragaman buah dan bunga dalam pendidikan dapat berperan membantu pengajar dalam melaksanakan suatu proses pembelajaran di taman kanak-kanak, khususnya untuk mengatasi masalah kurangnya alat peraga. Selain itu pemanfaatan bahan alam bagi siswa atau dalam hal ini anak-anak dapat dijadikan sebagai suatu pengembangan baru dalam melaksanakan kegiatan pembelajaran menggunakan media tumbuhan sebagai sarana permainan. Berkenaan dengan pembelajaran di TK tersebut, pembelajaran menggunakan media tumbuhan yang ada di lingkungan sekitar dapat dimanfaatkan untuk mengubah pola pembelajaran konvensional ke pola pembelajaran permainan.

Dalam mengajar, pengajar maupun siswa TK memerlukan sarana pendukung yang dapat membantu proses belajar mengajar yang lebih interaktif. Pola pengajaran yang interaktif dan menyenangkan dapat diterapkan dengan memanfaatkan visualisasi yang menarik ke dalam pendidikan untuk meningkatkan kemampuan siswa dalam menyerap materi pelajaran.
Anak-anak umumnya memiliki keterbatasan pengetahuan tergantung pada informasi yang diterimanya. Visualisasi cenderung digunakan untuk menerima informasi dan mengingatnya dalam otak. Pada umumnya anak-anak memiliki daya imajinasi yang cukup tinggi. Sehingga dalam menyampaikan materi pembelajaran tentang suatu materi yang diberikan harus memperhatikan aspek yang nyata dapat menumbuhkan imajinasi, agar dapat dibayangkan hal yang sesungguhnya terjadi atau bentuk nyata yang dapat digambarkan melalui visualisasi.

Pembelajaran dengan pemanfaatan tumbuhan dapat dipadukan dengan adanya unsur permainan yang interaktif, sehingga merupakan suatu metode pembelajaran yang menyenangkan bagi anak-anak untuk belajar.

Sumber belajar sendiri merupakan sarana atau fasilitas pendidikan yang merupakan komponen penting untuk terlaksananya proses belajar mengajar di sekolah. Pelaksanaan kegiatan belajar mengajar guru di sekolah sewajarnya memanfaatkan sumber belajar. Pemanfaatan sumber belajar merupakan hal yang sangat penting dalam konteks belajar mengajar, 
karena sumber belajar dapat membantu dan memberikan kesempatan belajar serta memberikan pengalaman belajar yang kongkrit, dan dapat memperluas cakrawala siswa, sehingga tujuan pembelajaran dapat tercapai sesuai dengan apa yang direncanakan. Pembelajaran dengan memanfaatkan tumbuhan di lingkungan sekolah dapat membantu mengimplementasikan tujuan pembelajaran dengan cara memperkaya bahan pengajaran guru sehingga mampu meningkatkan kualitas proses belajar mengajar di sekolah.

Objek lingkungan yang dimanfaatkan sebagai sumber pembelajaran dapat dianalisis secara kurikuler. Upaya ini dapat menjadi wahana proses belajar mengajar yang dapat menjadi fasilitas tambahan (variasi) sumber belajar bagi guru dan siswa. Dalam penggunaan sumber belajar siswa harus diarahkan oleh guru. Jadi guru bukan satu-satunya sumber belajar melainkan ada sumber lain yaitu lingkungan, yang bemanfaat terhadap pemahaman dan pengalaman siswa. Sebenarnya sumber balajar lain banyak terdapat di sekeliling manusia, tidak mesti harus memakai peralatan yang mahal, bahan yang sederhana pun bisa dijadikan sumber belajar yang berharga. Sebagai mahkluk hidup, seorang anak selain berinteraksi dengan temannya juga berinteraksi dengan sejumlah mahkluk hidup dan benda mati yang ada disekitarnya.

Manusia telah memanfaatkan tumbuhan untuk memenuhi kebutuhannya sejak ribuan tahun yang lalu. Untuk memudahkan komunikasi pemanfaatan tumbuhan maupun untuk tujuan lainnya maka kelompok masyarakat membuat nama jenis/spesies tumbuhan. Nama lokal untuk setiap spesies tumbuhan pada umumnya berbeda antara satu kelompok masyarakat atau etnis dengan kelompok lainnya. Sebagai contoh Eurycoma longifolia Jack atau yang lebih dikenal dengan tanaman pasak bumi memiliki nama lokal bidara pahit (Melayu), tungkek ali (Minangkabau), petola bumi (Riau), empedu tanah (Jambi) dan merule (Kalimantan Timur).(Achmad et al., yang dikutip dalam Silalahi 2016).

Pemanfaatan sumberdaya alam dan lingkungannya serta kepedulian masyarakat sekitar pada kawasan konservasi sejalan dengan program konservasi keanekaragaman hayati dan ekosistemnya serta pemberdayaan masyarakat lokal. Pemanfaatan pekarangan merupakan bagian dari pemanfaatan sumberdaya alam dan lingkungan yang memberi manfaat bagi manusia. Pekarangan adalah lahan terbuka yang terdapat di sekitar rumah tinggal. Lahan ini jika baik akan memberikan lingkungan yang menarik nyaman dan sehat serta menyenangkan sehingga membuat kita nyaman tinggal di rumah. Selain tanaman hias, buah-buahan, sayuran, rempah-rempah, tanaman obat adalah salah satu tanaman produktif yang dapat dikembangkan atau di budidayakan di pekarangan.

Tanaman di sekitar lingkungan dapat dimanfaatkan oleh para orang tua sebagai media pendidikan dan permainan. Permainan tradisional khususnya dari alam merupakan salah satu dari sekian banyak warisan budaya negeri kita. Permainan alam mengajarkan orang tua dan anak untuk berkreasi, lebih dekat dengan alam dan bersyukur atas anugerah Tuhan Yang Maha Esa yang berupa alam di sekitar kita, dengan bermain dan belajar melalui bahan-bahan yang berasal dari alam dimulai dari mengumpulkan, membuat hingga menjadi permainan merupakan suatu proses. Tahap-tahap yang dilalui mengajarkan anak-anak untuk menghargai proses, tangguh, dan survive dalam menghadapi tantangan di masa depan, dimana itu tidak diajarkan di permainan modern.

Kegiatan bermain, selain sebagai pekerjaan utama anak-anak, juga bermanfaat untuk mengembangkan serta meningkatkan serta meningkatkan kemampuan tumbuh kembang anak. Kemampuan tumbuh kembang anak bukan hanya kemampuan motorik dan kognitif saja, namun juga kemampuan dasar lainnya seperti perkembangan emosi dan psikis. Kemampuan dasar inilah yang melatih si kecil untuk dapat berinteraksi dengan lingkungan, berani dan percaya diri, tidak mudah menyerah, menaati aturan, sigap dalam menghadapi bahaya yang datang, serta kecerdasan lain yang tak bisa didapatkan di lingkungan sekolah formal.

\subsection{Mewarnai Bunga}

Memiliki gadis kecil yang lahir di dunia pasti seorang ibu tidak pernah bosan untuk mendandaninya, terlebih si kecil juga suka 
menggunakan aksesoris cantik. Bando merupakan salah satu aksesoris yang dapat orang tua perkenalkan pada si kecil. Alat dan Bahan menggunakan Spidol dan bunga. Cara mewarnai meliputi: pilihlah bunga yang akan diwarnai dan ambil spidol sesuai selera.

Warnai bunga yang ada di sekitar kita.

1.2 Tema Buah

\subsubsection{Yoyo Putar dari Terung Bulat}

Di usia dini, anak-anak paling menyukai gerakan memantul-mantul karena dianggap lucu oleh anak. Permainan ini dapat orang tua gunakan untuk mengalihkan perhatian anak-anak terutama saat menangis. Tidak hanya itu. Tidak hanya itu, untuk anak yang telah duduk di bangku SD kelas 5-6, orang tua dapat mengajarinya sifat elastisitas karet serta bentuk dari gelombang pada permainan yoyo putar ini.

\section{Alat : Guntung/Pisau/Cutter}

Bahan : satu buah terung bulat, satu lidi berukuran $3 \mathrm{~cm}$, dan 1 buah karet gelang yang sudah putus.

Cara Membuat: (1) Tangkai buah terung dipotong sampai habis; (2) Tepat pada bagian yang dipotong, julurkan karet gelang dengan posisi tidak sama panjang. Bagian karet yang pendek diletakkan di atas terung sementara bagian yang panjang dibiarkan terurai; dan (3) Bagian atas tengah terung ditusuk menggunakan lidi hingga karet pendek di atasnya tidak lagi kelihatan (masuk ke dalam terung).

\subsubsection{Gerobak dari Terung Bulat}

Walau terlihat sederhana, gerobak mainan dari terung bulat ini sangatlah menyenangkan bagi si kecil, terutama untuk ia yang baru berusia di atas 1 tahun.

\section{Alat : Pisau/Cutter}

Bahan : dua buah terung bulat, satu daun mangga, benang/tali yang dibuat dari kulit batang pisang yang sudah kering, lidi.

Cara Membuat: (1)Siapkan lidi kira-kira ukuran $10 \mathrm{~cm}$; (2) Tusuk kedua ujung lidi pada buah terung bulat yang dijadikan sebagai roda gerobak, masing-masing kirakira sedalam $2 \mathrm{~cm}$; (3) Bungkus lidi yang berada di antara 2 buah terung bulat dengan selembar daun mangga; (4) Tusuk ujung daun mangga dengan lidi sehingga kedua ujung daun mangga saling menyatu satu sama lain; dan (5) Kedua ujung daun mangga yang telah menyatu, terakhir dilihat dengan benang. Fungsi benang tersebut sebagai penarik gerobak.

1.2.3 Etek-etek dari Terung Bulat

Alat : Pisau / Cutter

Bahan : satu buah terung bulat, batang lidi yang masih basah (bisa dilengkungkan)

Cara Membuat: (1) Siapkan batang lidi berukuran $15 \mathrm{~cm}$. Lengkungkan batang lidi tersebut lalu tusukkan kedua ujung lidi pada buah terung; (2) Tepat dibagian tengah atas buah terung, tusukkan juga satu batang lidi berukuran $10 \mathrm{~cm}$ secara tegak lurus; (3) Kemudian selipkan dua batang lidi yang berdekatan berukuran $15 \mathrm{~cm}$ pada batang lidi yang ditusukkan lurus tadi sehingga membentuk sudut siku-siku.

\subsubsection{Tusuk Sate dari buah jeruk}

Walau terlihat sederhana, anak sangat suka dengan mainan anak, misalnya membuat sate dari jeruk. Bahan yang dibutuhkan meliputi 3 buah jeruk dan lidi. Cara membuat yaitu potong lidi sesuai selera dan tusukkan lidi ke jeruk yang sudah disiapkan.

\section{METODE}

Kegiatan pengabdian kepada masyarakat dilaksanakan pada hari Selasa tanggal 16 Oktober 2018 yang bertempat di TK LABIBAH yang berlokasi di jalan Ruhui Rahayu II RT. 99 No. 71 Balikpapan kodepos 76115. Alat dan bahan yang digunakan adalah : lidi, gunting, buah jeruk, spidol warna, daun-daunan, dan terung bulat.

Cara kerjanya : 1) Pemateri menjelaskan ke guru dan siswa TK LABIBAH bagaimana membuat mainan tradisional dari bunga dan buah, 2) Pemateri menyiapkan alat dan bahannya sambil di bagikan ke siswa, 3) Pemateri mempraktekkan cara membuat mainan tradisional dari bunga dan buah 4) Siswa memperhatikan yang disampaikan pemateri sambil membuat keterampilannya, dan 5) Guru 
membantu siswa cara membuat mainan tradisional.

\section{HASIL DAN PEMBAHASAN}

Persiapan kegiatan pengabdian kepada masyarakat di TK LABIBAH dimulai sejak awal September 2018 meliputi kunjungan ke TK LABIBAH pertama, yang dilaksanakan pada hari jumat tanggal 21 September 2018, menentukan sasaran pengabdian masyarakat. Sedangkan kunjungan ke TK LABIBAH kedua, yang dilaksanakan pada hari jumat tanggal 28 September 2018, untuk menentukan tema dari pelaksanaan acara dan konsep acara.

\section{Realisasi Kegiatan Pengabdian Kepada Masyarakat}

Tempat kegiatan di TK LABIBAH dan dihadiri oleh Guru TK LABIBAH, siswa TK LABIBAH, orang tua dan dosen FKIP Universitas Balikpapan.

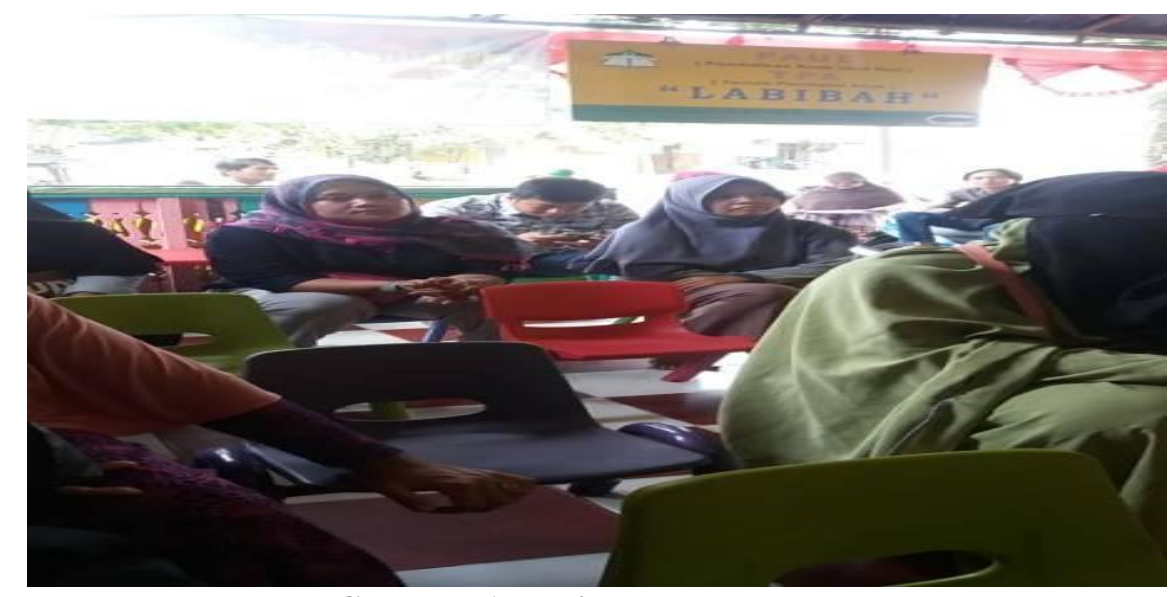

Gambar 1 Kegiatan Pembukaan

Kegiatan Pembukaan yang dihadiri oleh wali murid TK LABIBAH Sepinggan, supaya orang tua mengetahui bahwa buah dan bunga dapat

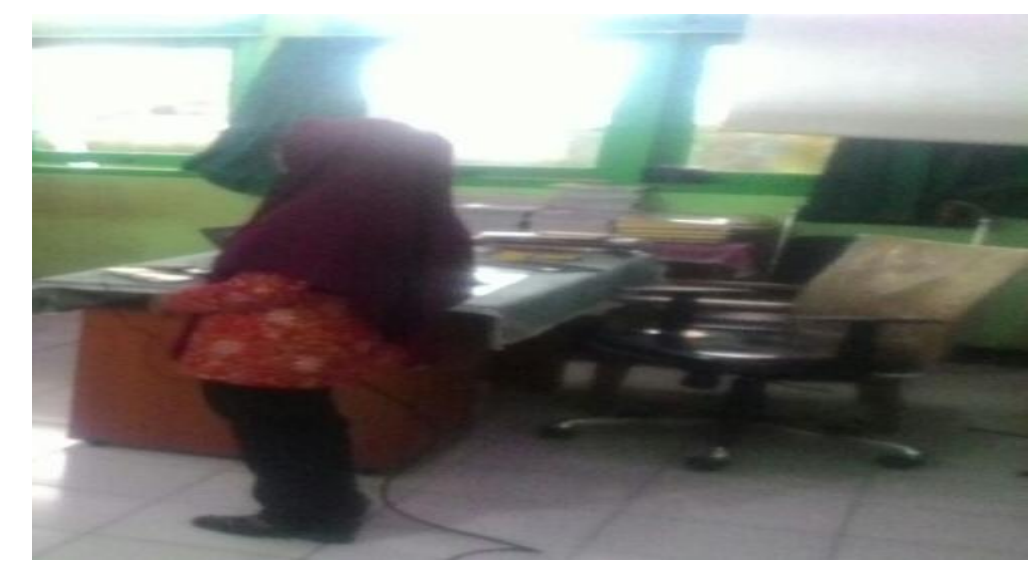

Gambar 2 Sambutan dan Penyampaian Materi

\section{Kegian Penyampaian Materi}

Pada sesi ini, sebagai Pemateri adalah Ibu

Rahayu Sri Waskitoningtyas memberikan edukasi kepada siswa siswi TK LABIBAH mengenai keanekaragaman Bunga dan Buah sebagai media permainan. Pemateri memberikan penjelasan cara membuat permaianan dengan bunga dan bunga. Sehingga pembelajaran dapat berjalan dengan menyenangkan. siswa tampak dijadikan sebagai media permainan untuk mengembangkan kreativitas anak antusias mengumpulkan bahan yang sudah disediakan oleh ibu Rahayu Sri Waskitoningtyas. Bahan-bahan yang disediakan antara lain spidol warna, lidi, buah terong, buah jeruk, dan tanaman bunga yang ada di lingkungan TK LABIBAH. Dunia anak sering dengan kegiatan bermain. Biasanya anak menggambar di buku tulis atau gambar. Hal tersebut bisa diganti dengan 
mewarnai pada tanaman yang masih hidup. Anak

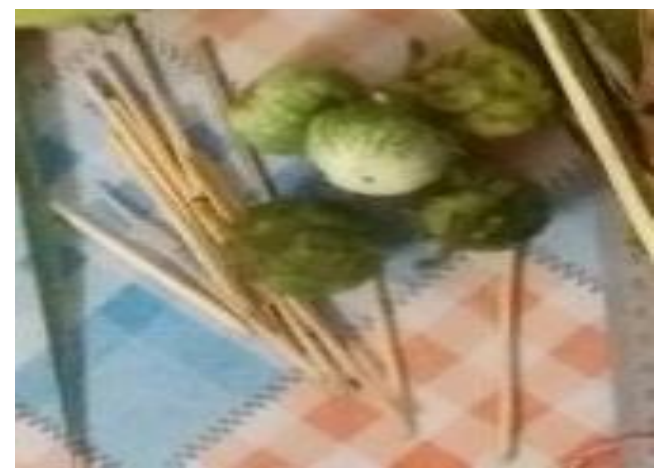

Gambar 3 Pengumpulan Bahan dari Buah

Siswa dibimbing oleh Ibu Rahayu Sri Waskitoningtyas secara bersama-sama melakukan dan membuat permainan dari bunga dan buah, sekaligus diikuti oleh Guru TK LABIBAH. Dengan menumbuhkan permainan

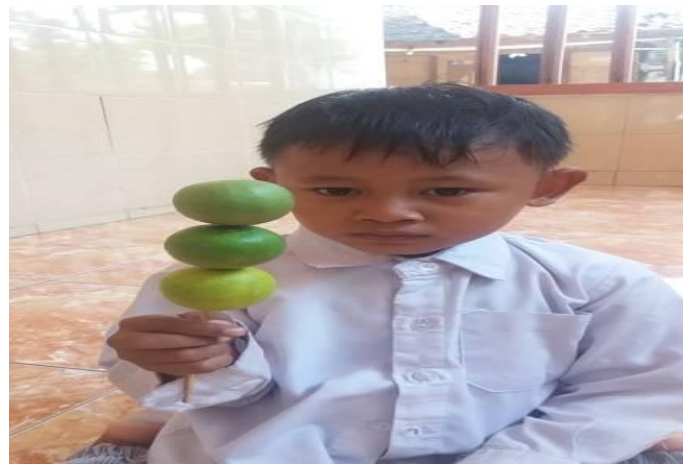

Gambar 5 Permainan Tusuk Sate dari jeruk

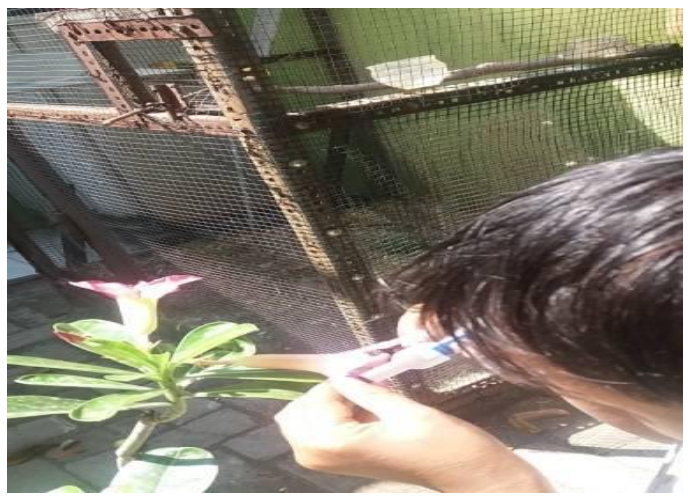

Gambar 7 Mewarnai Bunga

\section{SIMPULAN DAN SARAN}

Simpulan dari kegiatan Pengabdian Kepada Masyarat ini adalah Kegiatan pengabdian kepada masyarakat yang dilaksanakan di TK LABIBAH, berjalan dengan lancar, dengan harapan yaitu siswa dapat mengaplikasikan materi yang telah disampaikan, terutama tentang permainan anak dari bunga dan buah, sehingga anak menyukai bisa mewarnai bunga atau daunnya.

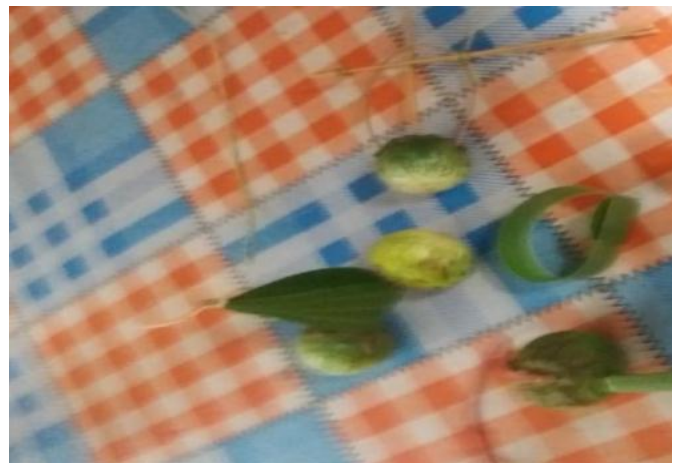

Gambar 4 Contoh Permainan Anak dari Buah Terong

tradisional yang dibuat dari bunga dan buah, anak sangat berantusias untuk membuat permainan tradisonal itu. Selain itu, permainan tradisional bisa menambahkan kreativitas anak.

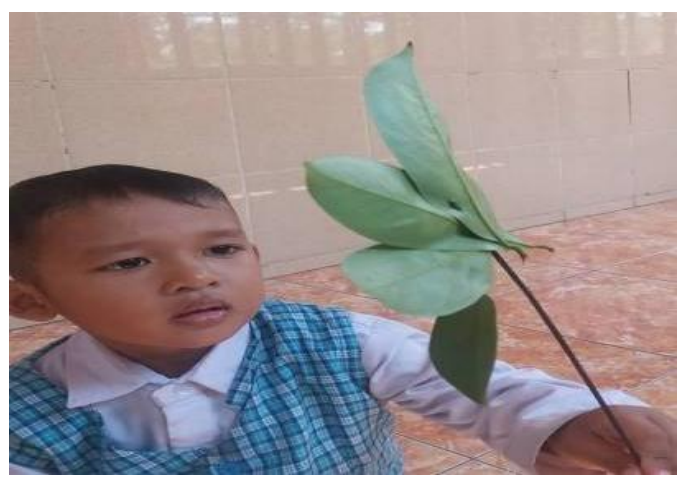

Gambar 6 Permainan Susun Daun

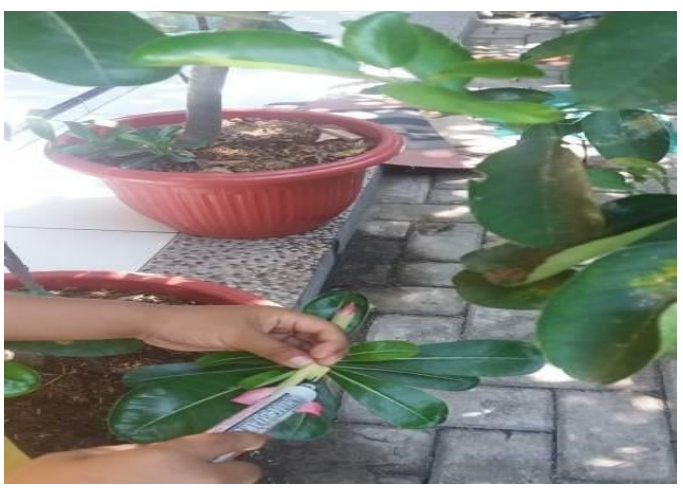

permainan tradisional. Selain itu siswa juga sadar akan pentignya permainan tradisional sehingga menumbuhkan kreativitas anak. Anak bisa mewarnai bunga dan daun yang ada di rumah sehingga anak tidak perlu mencoret-coret tembok. Orang tua bisa memanfaatkan buah terong dan jeruk untuk dibuat permainan sehingga anak tidak mengganggu orang tua. 
Selain itu orang tua bisa melath anak untuk menyusun daun dengan lidi.

Saran kepada guru pengajar di TK LABIBAH supaya mengajarkan anak kreativitas dalam bermain sehingga anak suka dengan mainan tradisional, sedangkan untuk orang tua adalah biasakan anak mengenal permainan tradisional.

\section{DAFTAR PUSTAKA}

Achmad, S. J., Syah, Y.M., Hakim, E. H., Juliawaty, L. D, Makmur, L., \& Mujahidin, D. (2009). Ilmu kimia dan kegunaan tumbuh-tumbuhan obat Indonesia. Bandung: Institut Teknologi Bandung.

Fadhilah, Chasana, \& Anik. 2018. Kitab Dolanan Alam Sebuah Kitab Rahasia Dolanan Alam Untuk Anak. Banten: Aryoko Indonesia.

Kusmawardani, Dian. 2018. Ibuku Adalah Sekolah Terbaikku. Banten: Aryoko Indonesia.

Silalahi, Marina. 2016. Pengetahuan Mahasiswa Terhadap Keanekaragaman Tumbuhan Di Lingkungan Kampus. Al-Kauniyah Jurnal Biologi. 9(1), 2016. 